In sum, it appears that the Illinois Supreme Court has adopted a liberal attitude in applying the subject-title and amendatory requirements of the constitution. Little, if anything, seems to be left of the requirement that amended provisions must be reprinted at length in the amending act even where the new act is expressly amendatory. The impossibility of reprinting all acts in any way affected by the new legislation, and increased use of convenient annotated compilations have led the Court to inquire whether the questioned provision is sufficiently "complete in itself" that no other act need be consulted to determine the law on that part of the subject. It is here that an attack upon a statute expressly or impliedly amendatory is most likely to succeed. ${ }^{.7}$ Thus, the declining effectiveness of the amendment provision has placed the burden of procedural safeguard upon the subject-title requirement.

$\pi$ By way of anticipation, one might speculate upon section 770 of the new Illinois Savings and Loan Act. Ill. Rev. Stat. (1955) c. 32, \$770.

This act is titled "An Act to revise and codify the laws in relation to Savings and Loan Associations and to provide penalties for the violation thereof and to repeal an Act therein named." Section 770 deals with joint accounts, trust accounts, and payment-on-death accounts. It contains for the first time provisions which might well be construed to "amend" the Probate Act insofar as it purports to allow a testamentary disposition of the account funds without complying with the formalities required for the execution of wills. Consult, for example, the discussion to that effect in Bank Accounts: Transfer of Property at Death, 23 U. of Chi. L. Rev. 289, 296-97, 301-8 (1956).

Assuming that the provision is so construed, what is the likelihood of successful attack on Art. IV, $\$ 13$ grounds? Briefly the provision could be upheld on the following grounds: 1) The act is a clear attempt at general revision and codification and as such is not subject to "amendatory" prohibitions; 2) The act is complete in itself-there is no need to refer to the Probate Act with respect to testamentary dispositions of such trust accounts; and 3) The act relates to the single general subject of Savings and Loan Associations to which the effects on their trusts accounts is "germane." On the other hand, it can be argued against the provision that: The provision creates an ambiguity with respect to testamentary dispositions which may have been unexpected and unintended by the parties despite the signing of a signature card agreement. See Estate of Schneider, 6 Ill.2d 180, 127 N.E.2d 445 (1955), and consult 23 U. of Chi. L. Rev. 289 (1956). Furthermore this is an extraordinary departure from established custom and usage which should have been indicated in the title. The policies with respect to the probate of wills and administration of estates designed to protect creditors of the estate are firmly established.

\title{
THE UNION RIGHT TO REQUIRE EMPLOYER MEMBERSHIP
}

A recurrent problem of labor law has been the legality of union attempts to extend control over employers beyond the traditional sphere of wages, working conditions and employee membership. The Barbers Union ${ }^{1}$ attempted such an extension of control by three successive amendments ${ }^{2}$ to its constitution requir-

\footnotetext{
${ }^{1}$ The full title of the union is Journeymen Barbers, Hairdressers, Cosmetologists and Proprietors International Union of America, A.F. of L. Prior to the amendments requiring employer membership, the union went under the title of Journeymen Barbers, Hairdressers, and Cosmetologists' International Union of America.

${ }^{2}$ The first amendment provided that the employer must be a nonactive member who was not entitled to vote or to a seat in union meetings or to hold any office or to serve
} 
ing employers who display a union shop card and work with the "tools of the trade" to join the union. ${ }^{3}$ Union action based on these amendments occasioned a series of cases 4 in which the union attempted to recover the shop card from employers refusing to join. In these cases, the union's basic reliance has been on a contract or property right; the union argues that the card is union property which the union may dispose of at will, subject only to any contract which the union may have made concerning the card. Employers urge, however, that an economic weapon is involved, and that therefore traditional contract and property rights must give way to public policy limitations on the use of economic pressure, in particular the limitation concerning the legality of the union purpose in exercising the pressure.

The shop card cases ${ }^{5}$ involved similar facts: either the union was attempting to replevy the card from an employer who had agreed to abide by union standards, ${ }^{8}$ or the employer was suing to enjoin union removal of the card ${ }^{7}$ or the

as a delegate. The second amendment allowed the employer a voice and vote in meetings of the local union, but he was still ineligible to vote on matters "pertaining to wages, hours of labor, etc." He was also ineligible to hold any office in the local or international union or to act as a delegate or alternate to conventions. This amendment is set out in Riviello v. Journeymen Barbers Etc. Union, 109 Cal. App.2d 123, 125, 240 P.2d 361, 363 (1952). The last amendment provided that all members were entitled to "equal rights of membership, including the right to vote and hold office."

${ }^{3}$ The constitution provided for two types of organizations under the International: the employers' guild and the local union. At least one court had difficulty in distinguishing the two types of organizations: "There does not appear to be any definition of the difference between them. Article VIII, section 1 [of the union constitution] provides: 'Any competent barber ... may, upon application to and being accepted by the nearest local union or employers' guild, become a member thereof. . . ' What the functions of the guild as distinguished from the local union are, does not appear. Apparently, although the constitution does not say so, it is the intention that employers (as distinguished from working employers) shall join the guild, while employees shall join the union. The regulation of hours of labor, prices and wages, is exclusively in the union." Riviello v. Journeymen Barbers Etc. Union, 109 Cal.App.2d 123, 125, 240 P.2d 361, 363 (1952).

4 Head v. Local Union No. 83, Journeymen Barbers, 262 Ala. 84, 77 So.2d 363 (1955); Riviello v. Journeymen Barbers Etc. Union, 109 Cal.App.2d 123, 240 P.2d 361 (1952); Riviello v. Journeymen Barbers Etc. Union, 88 Cal.App.2d 499, 199 P.2d 400 (1948); Barbers Union v. Ind. Com., 128 Colo. 121, 260 P.2d 941 (1953); Rainwater v. Trimble, 207 Ga. 306, 61 S.E.2d 420 (1950); DiLeo v. Daneault, 329 Mass. 590, 109 N.E.2d 824 (1953); Kerkemeyer v. Midkiff, — Mo. -, 299 S.W.2d 409 (1957); Journeymen Barbers, etc., Local 687 v. Pollino, 22 N.J. 389, 126 A.2d 194 (1956); Simon v. Journeymen Barbers, \&c., Union, Local No. 315, 11 N.J. 448, 94 A.2d 840 (1953); Foutts v. Union, 155 Ohio St. 573, 99 N.E.2d 782 (1951); Wisconsin E.R. Board v. Journeymen Barbers, 272 Wis. 84, 74 N.W.2d 815 (1956); Wisconsin E.R. Board v. Journeymen Barbers, 256 Wis. 77, 39 N.W.2d 725 (1949).

${ }^{5}$ Ibid.

${ }^{6}$ Head v. Local Union No. 83, Journeymen Barbers, 262 Ala. 84, 77 So.2d 363 (1955) (suit by union to enjoin retention by employer); DiLeo v. Daneault, 329 Mass. 590, 109 N.E.2d 824 (1953) (counterclaim by employer for injunction); Journeymen Barbers, etc., Local 687 v. Pollino, 22 N.J. 389, 126 A.2d 194 (1956); Wisconsin E.R. Board v. Journeymen Barbers, 272 Wis. 84, 74 N.W.2d 815 (1956); Wisconsin E.R. Board v. Journeymen Barbers, 256 Wis. 77, 39 N.W.2d 725 (1949) (suit by employer to enjoin picketing). 
picketing following the removal. ${ }^{8}$ Most of these cases did not discuss the legality of the union purpose of obtaining employer membership. ${ }^{9}$ Nearly all of the cases under the first two amendments ${ }^{10}$ held against the union on the ground that the membership offered the employer was discriminatory; ${ }^{11}$ he could neither vote nor hold office, but was required to pay dues. Under the most recent amendment, ${ }^{12}$ which affords the employer full membership rights, the cases are in conflict.

Some courts, ${ }^{13}$ holding in favor of the union, have relied upon an agreement by the employer to allow union removal of the card for "any cause."14 However, it may be questioned whether this rationale eliminates the necessity for considering the union's purpose of obtaining employer membership, since the legality of such purpose would be revelant to a determination of whether the agreement violates public policy. ${ }^{15}$ Courts have often severely limited tradi-

${ }^{7}$ Riviello v. Journeymen Barbers Etc. Union, 109 Cal.App.2d 123, 240 P.2d 361 (1952); Riviello v. Journeymen Barbers Etc. Union, 88 Cal.App.2d 499, 199 P.2d 400 (1948); Barbers Union v. Ind. Com., 128 Colo. 121, 260 P.2d 941 (1953); Rainwater v. Trimble, 207 Ga. 306, 61 S.E.2d 420 (1950); Kerkemeyer v. Midkiff, - Mo. -, 299 S.W.2d 409 (1957) ; Foutts v. Union, 155 Ohio St. 573, 99 N.E.2d 782 (1951).

${ }^{8}$ Simon v. Journeymen Barbers, \&c., Union, Local No. 315, 11 N.J. 448, 94 A.2d 840 (1953) ; Wisconsin E.R. Board v. Journeymen Barbers, 256 Wis. 77, 39 N.W.2d 725 (1949).

${ }^{\circ} \mathrm{A}$ few courts have explicitly disclaimed the necessity of considering the legality of the union purpose. Dileo v. Daneault, 329 Mass. 590, 596, 109 N.E.2d 824, 828 (1953); Foutts v. Union, 155 Ohio St. 573, 577, 99 N.E.2d 782, 785 (1951).

${ }^{10}$ Consult note 2 , supra.

11 Riviello v. Journeymen Barbers Etc. Union, 109 Cal.App.2d 123, 240 P.2d 361 (1952); Riviello v. Journeymen Barbers Etc. Union, 88 Cal.App.2d 499, 199 P.2d 400 (1948); Barbers Union v. Ind. Com., 128 Colo. 121, 260 P.2d 941 (1953); Simon v. Journeymen Barbers, \&c., Union, Local No. 315, 11 N.J. 448, 94 A.2d 840 (1953). Contra: Rainwater v. Trimble, 207 Ga. 306, 61 S.E.2d 420 (1950); Foutts v. Union, 155 Ohio St. 573 , 99 N.E.2d 782 (1951).

12 Consult note 2 , supra.

${ }^{13}$ Rainwater v. Trimble, 207 Ga. 306, 61 S.E.2d 420 (1950) ; Foutts v. Union, 155 Ohio St. 573, 99 N.E.2d 782 (1951).

16 The back of the shop card contained the statement: "The person or persons displaying this card do so in accordance with the rules stated below, and it is agreed, by the person or persons displaying this card, that for any violation of the rules below stated, he or they will give peaceable possession of the same to the local union under whose jurisdiction it is to be displayed, .... also, that the same will be given into the peaceable possession of the General President-Secretary-Treasurer of the ... Union ... on demand." In addition, the Rules Governing Union Shop Cards contained the following provision: ". . the person or persons displaying the Shop Card shall specifically agree: ... (c) To peaceably give up said Shop Card on demand of the local union . . . for the violation of any local or international laws. (d) To peaceably give up said Shop Card ... . in case of the suspension or disbandment of the local union which issued it, or for any cause, when called upon to do so."

${ }^{15}$ A party to a contract cannot agree in advance to be bound by illegal modifications or amendments to that contract. If one of the "laws" passed subsequent to the agreement provided that the employer should enter into price-fixing agreements with other employers, it is difficult to see how any court would permit removal for breach of that "law." Other courts have intimated that the subsequent modifications must be "reasonable," "legal," and within the contemplation of the parties at the time the original contract was made. "Even 
tional contract and property rights in order to effectuate public policy concerning the use of economic pressure in labor-management relations. While these limitations have usually been imposed on contract and property rights of employers ${ }^{16}$ there would seem to be no reason why public policy cannot also limit union rights. The amount of litigation in this field shows a recognition by both the union and employers that shop cards are an important form of economic pressure. In the first place, shop cards are a sign of union approval; in unionized areas, at least, absence of the card may cause a partial, customer boycott. ${ }^{17}$ In addition, removal of the card often results in strikes and picketing. ${ }^{18}$ While it may be argued that a court could effectuate public policy limiting economic pressure by enjoining any strike ${ }^{19}$ caused by removal of the

in the absence of pertinent statutes governing the instant case, we doubt the right of the Union to arbitrarily or capriciously refuse union recognition to one who conforms to all its reasonable and legal rules. We think it is unquestionably true that [the employer], under his contract with the Union, was required to abide by all such reasonable and legal rules which might be adopted by it. However he could not bind himself by contract to obey a rule adopted in the future which would compel a course of conduct contrary to the public policy of the State of Colorado as declared by the legislature." Barbers Union v. Ind. Com., 128 Colo. 121, 130, 260 P.2d 941, 946 (1953).

"If the object sought [by the union] is contrary to the public policy of the Commonwealth a court of equity will not lend its aid in accomplishing that object, whatever agreement the [employer] may have made." DiLeo v. Daneault, 329 Mass. 590, 595, 109 N.E.2d 824, 827-28 (1953).

Other courts, deciding for the union, have argued that the shop card is a sign of union approval and cannot be displayed after withdrawal of such approval without misleading the public. Head v. Local Union No. 83, Journeymen Barbers, 262 Ala. 84, 77 So.2d 363 (1955); Foutts v. Union, 155 Ohio St. 573, 99 N.E.2d 782 (1951); Wisconsin E.R. Board v. Journeymen Barbers, 272 Wis. 84, 74 N.W.2d 815 (1956). However, even if the usual barbershop customer notices the card-it being only $9 \frac{1}{2}$ by $7 \frac{11}{2}, 329$ Mass. 590, 592, 109 N.E.2d 824, 826-it may be doubted whether union loyalty would cause him to patronize only union shops, except to the extent that patronage of non-union shops requires crossing picket lines. But if the card is, as the union contends, a symbol of approval which will affect the employer's business, then it would appear that the manipulation of the card is a form of coercion which must be judged, along with other forms of economic pressure, in terms of the lawfulness of the objective.

${ }^{26}$ E.g., Republic Aviation Corp. v. NLRB, 324 U.S. 793 (1945), where employee solicitation on employer property was upheld in spite of the employer's anti-solicitation regulation.

${ }^{17}$ "There was evidence of various employers who had operated union shops and displayed the union card for periods ranging from nine to twenty-five years, to the effect that, if the union card was removed from their shops, their business would decrease. The estimate of decrease ranged from $20 \%$ to $50 \%$." Rainwater v. Trimble, 207 Ga. 306, 307, 61 S.E.2d 420,421 (1950).

${ }^{18}$ Article VII, $\$ 3$ of the constitution provides: "When the Union Shop Card is removed from any shop for violation of the laws, rules, regulations and agreements, all members employed therein shall immediately leave the employment of said shop. For failure to comply with the above the members will be subject to suspension and to penalties as provided for in Article XIII of this Constitution." This provision is set out in Barbers Union v. Ind. Com., 128 Colo. 121, 125, 260 P.2d 941, 944 (1953).

${ }^{18}$ Although it would seem that, at the present time, barbering would not fall within any definition of interstate commerce, there remains the possibility that the Labor Management 
card, it would seem that if there is to be litigation concerning shop cards, there is little reason to wait for a strike in order to determine the legality of the purpose behind the union's use of economic pressure. In any event, forcing the employer to raise the legality of union's purpose by means of a suit to enjoin picketing will not avoid the necessity of deciding the issue.

Some courts have accepted the employers' argument that union attempts to remove the card should be considered in light of public policy limitations on economic pressure. ${ }^{20}$ However, the analysis of public policy is sometimes erroneous. Thus, some courts ${ }^{21}$ holding against the union rely on statutes forbidding employer financial contributions to labor organizations-statutes designed to eliminate the dangers of the company union and not to prevent the payment of dues by an employer who is a member of a labor organization. ${ }^{22} \mathrm{~A}$ more recent case, perhaps, comes closer to the relevant public policy in this field by holding against the union on the ground that employer membership would be destructive of the principles of collective bargaining. ${ }^{23}$

The shop card cases reveal three union objectives which must be analyzed in terms of their lawfulness: price fixing, the obtaining of employer dues, and the subjection of the employer to the control inherent in union membership. Union price fixing may be motivated by two purposes. In employer-dominated unions, the purpose would be solely to obtain monopoly profits for employers. Such a

Relations Act could be found to be applicable. If it is, two problems then arise: is the union attempt an unfair labor practice, and are the states powerless to act whether it is or not? On the latter point, the most recent decisions of the Supreme Court indicate that state power to deal with labor relations matters affecting interstate commerce has been completely displaced where the NLRB has declined to exercise its jurisdiction but has not ceded jurisdiction to a state agency-court or labor board. Guss v. Utah Labor Board, 353 U.S. 1 (1957) ; Meat Cutters v. Fairlawn Meats, 353 U.S. 20 (1957); San Diego Unions v. Garman, 353 U.S. 26 (1957).

${ }^{20}$ Barbers Union v. Ind. Com., 128 Colo. 121, 260 P.2d 941 (1953) ; DiLeo v. Daneault, 329 Mass. 590, 109 N.E.2d 824 (1953); Kerkemeyer v. Midkiff, — Mo. -, 299 S.W.2d 409 (1957); Wisconsin E.R. Board v. Journeymen Barbers, 256 Wis. 77, 39 N.W.2d 725 (1949).

${ }^{21}$ Barbers Union v. Ind. Com., 129 Colo. 121, 260 P.2d 941 (1953); Dileo v. Daneault, 329 Mass. 590, 109 N.E.2d 824 (1953); Wisconsin E.R. Board v. Journeymen Barbers, 256 Wis. 77,39 N.W.2d 725 (1949).

=2 See Master Plumbers Ass'n of Albany v. Weir, 258 App.Div. 76, 15 N.Y.S.2d 889 (1939). A subsequent Colorado case, by way of dictum, indicated that the Colorado statute dealing with financial support by employers had been amended to permit employer-members to pay dues. Associated Master Barbers v. Journeymen Barbers, 132 Colo. 52, 285 P.2d 599 (1955). The Massachusetts statute was amended in 1956 to read: "An employer shall not be prohibited from paying regular initiation fees, dues and assessments to any labor organization in which he is a member or is eligible for membership." The Wisconsin statute was amended in 1951 by adding the proviso: "Provided, however, that it shall not be an unfair labor practice for an employer to become a member of the same labor organization of which his employees are members, when he and they work at the same trade."

${ }^{23}$ Kerkemeyer v. Midkiff, — Mo. -, 299 S.W.2d 409 (1957). 
purpose is clearly unlawful..$^{24}$ In employee-dominated unions, the purpose would be to protect union standards by making the employer better able to meet union wage demands. In other industries, where the employer's labor is not such an important factor-where hired labor constitutes a higher proportion of production costs-protection of union standards from destructive price competition may be achieved by fixing employee wages, a clearly lawful union activity. Where, as in the barbershop situation, the only feasible means of protecting union standards is by fixing self-employers' prices, it would seem that such price fixing should also be lawful, although in view of the blanket prohibition of most anti-trust statutes this result may require legislation. Moreover, courts which have sustained the imposition of union standards and membership on unwilling employers and employees on the ground that the union was merely protecting the wages of its members, ${ }^{25}$ have failed to see a further difficulty. Employers of union labor will undoubtedly concur in the union purpose of protecting their pre-wage profits, and there is no reason to believe that most self-employers would not also anticipate profits from a union price fixing scheme established for this purpose. Where the employers belong to the union, it would seem that at least part of the "union purpose" is the unlawful purpose of employers to obtain monopoly profits from price fixing.

Spokesmen for the Barbers Union have stated that one objective of the union drive for employer membership has been to obtain additional dues. ${ }^{26}$ The justification for this objective seems to be found in traditional union ob-

24 Endicott v. Rosenthal, 216 Cal. 721, 16 P.2d 673 (1932); People v. Sheldon et al., 139 N.Y. 251, 34 N.E. 785 (1893). See Union T. \& S. Bank v. Telephone Co., 258 Ill. 202, 101 N.E. 535 (1913); Harding v. American Glucose Co., 182 Ill. 551, 55 N.E. 577 (1899); Ford v. Chicago Milk Shippers' Ass'n, 155 Ill. 166, 39 N.E. 651 (1895); Richardson v. Buhl, 77 Mich. 632, 43 N.W. 1102 (1889); State v. Minneapolis Milk Co., 124 Minn. 34, 144 N.W. 417 (1913) ; Finck v. Granite Co., 187 Mo. 244, 86 S.W. 213 (1905) ; Leonard v. Poole, 114 N.Y. 371, 21 N.E. 707 (1889). Consult also annotation, Application of AntiTrust Laws to Combinations to Maintain Prices of Commodities as Affected by Reasonableness of Prices Fixed, 50 A.I.R. 1000 (1927).

${ }^{25}$ The self-employer cases are collected in two annotations and a recent law review note: Relief Against Union Activities as Affected by the Fact That Owner of Business Operates Without Outside Help or Is Doing Part of the Work, 13 A.L.R.2d 642 (1950), 2 A.L.R.2d 1196 (1948); The History and Current Status of the Self-Employer in the Law of Picketing, 41 Minn. L. Rev. 655 (1957). Some of the barbershop cases are collected in the annotation, Rights In Union Label, Shop Card, or Other Insignia Denoting Union Shop or Workmanship, 42 A.L.R.2d 709 (1955).

A recent example of a court's upholding the union's attempts to impose union standards is Flatt v. Barbers Union, - Tenn. -, - S.W.2d - 39 L.R.R.M. 2585 (1957). In the Flatt case, the employer alleged that the union was trying to force him to join the union and to raise his prices. The union denied the former charge but admittted that it was seeking to impose union standards. The union picketing was upheld on free-speech grounds.

20 "Local 191 admits that the financial aspect is present because in its brief it is asserted that the purpose of the union in amending its constitution to require that those proprietors who work with tools of the trade join the union was that 'employer-barbers should also pay." " Kerkemeyer v. Midkiff, — Mo. -, —, 299 S.W.2d 409, 412 (1957). 
jections to the "free rider."27 Since the union shop-justified on the ground that employees should pay for their share of the benefits of union wage fixingis a lawful union purpose, it might seem that employers may lawfully be required to pay for their share in the benefits ${ }^{28}$ of union price fixing. ${ }^{29}$ However, this argument must encounter all the objections to such price fixing, since compensation can hardly be demanded in return for an illegal activity. Nor does an avoidance of these objections necessarily mean that the employer must become a union member since there are devices other than union membership for securing contributions..$^{30}$

The basic union objective in obtaining employer membership-and also the basic danger ${ }^{31}$ of such membership from the employer's viewpoint-is in-

$2 \pi$ "The following is a quotation from the [union's] brief:

"Additionally, the working employer enjoys many benefits as a journeyman which were obtained only by unceasing and costly struggles of the barbers' union and its members. The prices he can get for his service, the regulated training under apprenticeship laws, the beneficent legislation regulating the trade and entrance to the trade, all were obtained and are being maintained through the efforts of the Journeymen Barbers, Hairdressers \& Cosmetologists International Union of America, A.F. of L., one of the oldest trade unions in the country. To require the working employer to share the expense of this beneficent work, of which he gets full advantage, is not only pre-eminently fair, but also consistent with basic American principles of distributing the costs among those who benefit by the expenditure.'" Wisconsin E.R. Board v. Journeymen Barbers, 256 Wis. $77,85,39$ N.W.2d 725,729 (1949).

${ }^{23}$ Of course, all employers may not benefit by price fixing. However, it would seem that while employers may disagree over the level at which the price should be fixed, most employers probably prefer some price fixing to free competition and can therefore be said to "benefit" from price fixing. If price fixing were detrimental to a majority of employers, it would seem doubtful that the union, even by coercion, could maintain a price-fixing scheme.

${ }^{2}$ As a condition of upholding the union purpose of obtaining employer dues, a court might require that, in order to prevent "discrimination," the employer be given an offer of full voting membership. However, the union imposition of dues on employers, without such an offer, might not be considered discriminatory if the "free rider" justification for employer dues is accepted. One aspect of the discrimination objection seems to be that employers must pay dues without receiving a compensating benefit. Since price fixing under the "free rider" argument provides such compensation for financial support from employers without the benefit of full voting membership, employer membership may have to be justified on grounds other than the prevention of discrimination.

${ }^{50}$ A simple, and obvious, device would be to "rent" the union shop card. Since the card is the property of the union, and since there is no contract governing its issuance, it would appear to be a simple matter for the union to receive a monthly compensation for its display and use. Precedent of a sort for a more direct approach is to be found in In re Ford Motor Company of Canada, 1 L.A. 439 (1946), where the arbitrator refused to award a union shop but did award a check-off compulsory upon all employees, union and non-union alike, who were within the bargaining unit.

${ }^{\text {IT }}$ A second danger involved in employer membership in employee unions is that of employer domination. In the barber business, where many shops have few if any employees, there is the possibility that employers will form a majority in the union. Moreover, even without a majority, there is the possibility that employers will dominate the union, since as a class they are more likely than employees to take an active part in union affairs. This is so because of the knowledge on the employer's part that the union is not representing his 
creased control over employers. Employer subjection to union discipline, with its sanctions of fines, suspensions, or dismissals, may lessen the employer's resistance to union demands both at the bargaining table and in day-to-day grievance adjustment. The ultimate union sanctions against recalcitrant employer-members would be the traditional strike with picketing, also available against non-members. However, courts might be more likely to sustain the legality of picketing against an employer-member, since such picketing might be viewed as enforcement of internal union discipline, rather than a union attempt to control matters traditionally within the employer's discretion. Yet the union objective of increasing control over employers would seem only slightly furthered by employer membership, and the Barbers Union has not shown the increased control to be necessary or socially desirable. There is no economic reason why union control could not be increased, even to the extent that the division of profits between labor and management is worked out within the political structure of a union containing employers and employees, rather than across the bargaining table. But absent a showing of compelling social advantage to the contrary, it would seem that the employer desire to remain separate from the union should be respected; the independence of the small enterpriser has been traditionally set at a high value in our society.

best interests, coupled with the employee's willingness to let that abstraction, the "union," handle his affairs, as it has in the past.

In the shop card cases, employer resistance to union membership may indicate one reason why the courts did not discuss the problem of employer domination; the union in these cases was undoubtedly employee-dominated and would not have attempted to force membership on employers were there a danger of employer domination involved. However, in the future, employers already in the union may attempt to force membership on other employers in order to achieve or maintain employer domination of the union. The nonactive membership offered the employers under the first union amendment may indicate the union's awareness of the danger of employer domination. In the light of the union's readiness to amend the constitution to afford the employers equal rights, it would seem that courts should not, unless the unions are put in a class with seamen, idiots and infants, strike down the union attempt on the ground that such a course of action will be detrimental to the union. However, a concern over the effects on the public of the elimination of one party to the labor-management dichotomy may lead to a reluctance to enforce the union's attempts.

\section{CONGRESS $v$. THE COURTS: LIMITATIONS ON CONGRESSIONAL INVESTIGATION}

The desirability of imposing judicial restraints on congressional investigations has been a controversial issue throughout much of American history. ${ }^{1}$

${ }^{1}$ As inquiries have ranged from liberal to conservative in motivation and character, liberals and conservatives have taken turns supporting and condemning congressional investigations. As one group urged intercession by the courts, the other group has argued against judicial intrusion upon legislative activities. Among the articles arguing against 